\title{
EFFECT OF UNDERSTANDING FINANCIAL MANAGEMENT, REGIONAL FINANCIAL ACCOUNTING SYSTEMS, EFFECTIVENESS OF INTERNAL CONTROL, AND COMMITMENT TOWARDS FINANCIAL PERFORMANCE OF NORTH SULAWESI PROVINCE
}

\author{
David Paul Elia Saerang ${ }^{1}$, Heince R. N. Wokas ${ }^{2}$, Robby J. Kumaat ${ }^{3}$, Christian Datu ${ }^{4}$ \\ ${ }^{1,2,4}$ Accounting Program, Economics and Business Faculty, Sam Ratulangi University, Jl. Kampus Bahu, \\ Manado City, 95115, Indonesia \\ ${ }^{3}$ Economics Program, Economics and Business Faculty, Sam Ratulangi University, Jl. Kampus Bahu, Manado \\ City, 95115, Indonesia
}

Corresponding e-mail : d_saerang@unsrat.ac.id

\begin{abstract}
This study aims to determine, the effect of understanding financial management, regional financial accounting system, effectiveness of internal control and organizational commitment towards financial performance of region and city governments in the province of North Sulawesi. The type of this research is quantitative. The population are all Regional Work Unit (SKPD) government financial managers of North Sulawesi, the respondents are 125 respondents as financial managers namely PPK-SKPD, Head of Finance and Financial Staffs. The Data method is using questionnaires and the analysis is using multiple regression analysis. The result shows that the understanding of financial management and effectiveness of internal control have a significant effect to the financial performance, while the regional financial accounting system and organizational commitment are not significant.

Keywords : Understanding Regional Financial Management, Regional Financial Accounting Systems, Effectiveness of Internal control, Organizational Commitment, Local Government Financial Performance
\end{abstract}

JEL Classification : H11, H53, H61

Article info:

Received 30 April 2019

Revised 28 May 2019

Accepted 10 June 2019

Available online 15 June 2019

\section{INTRODUCTION}

Government financial performance is a valuation of improving the quality and comparability government financial information. Through performance valuation, the success of the organization or work unit will be more seen from its ability, from its resources that have been managed, to achieve the results with the plans outlined in the strategic plan. After regional financial reform, the purpose of regional financial management is how to understand regional financial governance and internal control system to guarantee the actions of management in the transparancy information about regional financial management and commitment from organizations supported by an accounting system in order to monitor the organizational activities.

The application of accounting system in regional financial management is very reasonable because accounting can be a control tool that can be used to achieve government goals by improving people's prosperity through society empowerment. One component of internal control is supervision activities that deal with periodic or ongoing assessments from achievement/performance quality by management to determine that the internal control 
operates as expected before and they are modified according to the changes that occurred (Arens, 2003). Suwardjono (2005: 159) said that accounting will have a real impact in socioeconomics life if the information are produced can control the behavior of economic policy makers to get an achievement of social purposes and economic goals.

In certain situations of internal control system, accounting is one of the technical obstacles for executives in regional financial management. In the implementation, from many problems that exist in the local government, one of them is about accounting. This statement indicates that regional financial management in each work unit needs to be carried out carefully in order to resolve accounting problems and show the present financial information adequately. Mardiasmo (2002: 35) asserts that an institution's financial accounting system can run well, if there is a good financial management mechanism. This means that regional financial management that reflected in the APBD has a strategic position to actualize an accountable government management. Understanding of financial management regarding to the compliance of regulations and legislation is very necessary, the used of a computer-based accounting system is very necessary too to accelerate the implementation of reporting and monitoring activities that need to be observed, to be able to present adequate financial information in the form of financial statements, and commitments from leaders to directing the financial managers of their respective work units, having an adequate competence/knowledge in the area of regional financial management, especially the components of the internal control system to support the actualize of transparent and accountable financial management. Based on preliminary observations on districts and cities from Government in North Sulawesi Province, capability of SKPD Leaders in regional financial management, there are still SKPDs that are late in submitting Budget Work Plans (RKA-SKPD) Regional Financial Management Officials (PPKD) to be compiled. And in the implementation of regional expenditures, there are still SKPDs that are late in submitting Functional Accountability (SPJ) to PPKD as BUD. Beside that, PPKD Accounting Department, data realization of expenditure budget is less than $90 \%$. This shows that the SKPD's financial performance is still inadequate. Based on the previous background description, the problems in this research are as follows:

1. Does understanding of financial management take effect to the financial performance of District and City Regional Government in North Sulawesi?

2. Does the regional financial accounting system take effect to the financial performance of District and City Regional Government in North Sulawesi?

3. Does the effectiveness of internal control in local government take effect to the financial performance of District and City Regional Government in North Sulawesi?

4. Does the organizational commitment take effect the financial performance of District and City Regional Government in North Sulawesi?

This study aims to empirically examine all the formulation of existing problems. Benefits of this research for science, is to provide references to the accounting government especially regional financial management; for researchers, can add knowledge in the area of regional financial management; for the Regency and City Regional Governments of North Sulawesi province, is to contribute ideas how to do the implementation regional financial management and internal control systems.

\section{LITERATURE REVIEWS}

Stewardship theory describes a situation where management is not motivated by individual goals but rather to aim their main goals for the benefit of the organization. In the private sector, stewardship theory is if managers at a higher level for example CEOs who act as stewards will have a pro-organizational attitude when the company's management structure gives authority and high flexibility (Donaldson and Davis, 1989, 1991 ) Stewardship theory 
can be applied to public sector accounting research organizations such as government organizations (Morgan, 1996; Van Slyke, 2006 and Thorton, 2009) and other non-profits (Vargas, 2004; Caers Ralf, 2006 and Wilson, 2010). Based on this theory, government management is required to provide services (acting as stewards / servants) for the principal's interests, in this case are societies and agencies, therefore management in the regional government should act as a steward rather than as an agent.

Based on Stewardship Theory, middle managers in government organizations are more likely act as stewards than agents, so that the service to the community can be interpreted correctly and the result can increased the organizational performance. That also needs a commitment from local government to consistently increase the ability of middle and lower servants in each work unit by provide facilities both software and hardware so that the financial performance can be realized as what as expected.

1. Effect of Understanding Regional Financial Management on SKPD Financial Performance. Qualified human resources who are trained, have education in accordance with the financial sector and have the necessary experience in regional financial management. Abdul (2008) states that performance-oriented regional financial management shows the performance accountability that there is a link between the strategic objectives to be achieved with the amount of funds allocated so it can be assumed that good regional financial management has an influence to the performance of one agency or organization. Warisno's research (2009) found that the quality of human resources has a significant effect to financial performance of Jambi government. Erna Sari, et al (2013) showed the results that understanding the administration of regional finance had a positive effect to the performance of regional financial managers.

H1: Understanding regional financial management has a significant effect on SKPD's financial performance

2. Effect of regional financial accounting systems to SKPD financial performance. An adequate regional financial accounting system (SAKD) can not only provide to verify transactions so that funds can be traced according to their objectives, and check the authority, efficiency, and validity of learning funds, but the regional financial accounting system can also support the achievement of local government performance. The use of accounting system application accelerates the reporting process of regional financial statements. The implementation of regional financial information system is expected to be able to increase the usefulness of the system and to improve the user performance of financial management in regencies and cities.

H2: Regional Financial Accounting System has a significant effect on SKPD Financial Performance

3. Effect of internal control to SKPD's financial performance. Basically internal control acts to prevent as early as possible the occurrence of irregularities, waste, abuse, obstacles, errors and failures in achieving the purpose and the implementation of organizational tasks. Freeman (2003: 71) asserted that budget of government agencies are used as a monitoring control. This indicates, the supervision that carried out on the used of the budget reflected in APBD, is one form with supervision that carried out by the executive, which is an internal supervision carried out to guarantee the use of funds., there is an internal supervision intended to ensure the effectiveness of budget used. Abdul (2009) said that internal supervision affects the performance of local government, and help organizational members to carry out their responsibilities effectively and achieve a better performance. Almanda Primadona (2010) shows the results that among the independent variables, internal supervision has a greater influence on performance of the local government in Bandung. This shows that internal supervision can provide to support responsiveness, responsibility and accountability of the government. If the internal 
supervision is good, the impact of achievement performance in local government is also good.

H3: Internal supervision has a significant effect on SKPD's financial performance

4. Effect of variable commitment to the ability of preparing local government financial statement. Organizational commitment is a strong belief and support for the goals to be achieved by the organization, with a strong commitment can influence the State to release their best ability. According to Halim, et al. (2010), the importance of the commitment of regional financial management officials are to carry out reporting and financial accounting to produce reliable and timely financial reports. Research Jasman (2012), the result shows that organizational commitment has a positive and significant effect to the effectiveness of budget management. Azmi (2014) make a research about the effect of organizational commitment on Regional Financial Management Performance in Aceh Government which showed that the organizational commitment influences the performance of regional financial management.

H4: Organizational commitment has a significant effect on SKPD's financial performance

5. Effect of understanding financial management, regional financial accounting system, and the effectiveness of internal control government on SKPD's financial performance. Almanda Primadona (2010) states that internal control and regional financial management have sufficient correlation and contribute or influence the local government performance where is if internal control and regional financial management are good, the regional government performance is also good. Conversely, the worse internal control and regional financial management, the worse the performance of local government. The influence of internal control and financial management of the area is still quite close. This is due to the lack of quality human resources and lack of facilities and infrastructure so that fraud acts arise which make an impact to the performance of local government. Wawan and Lia (2009) stated that internal control and the implementation of regional financial accounting systems have a very strong relationship, it means that internal control which carried out effectively and continuously, can influence and make a good impact to the implementation of regional financial accounting system that have been applied and vice versa.

H5: Understanding regional financial management, regional financial accounting system and effectiveness of internal control have a significant effect on SKPD's financial performance.

\section{RESEARCH METHOD}

This research is an explanatory research that aims to explain the relationship or influence between research variables through hypothesis testing (Faisal, 2012). The type of research is in the form of survey, which the survey has chosen from questionnaire that distributed to the object of research. The object of the research is SKPD financial managers. The subjects in this research amount to 125 financial management officers. The sample of respondent was taken with the criteria, namely PPK-SKPD, Head of Finance Section, and financial staffs who worked more than 1 year in the office. The distribution and collection of questionnaires were carried out directly by researchers and / or couriers, who is alumni of Faculty of Economics and Business Sam Ratulangi University in accordance with the domicile of their respective districts and cities, by distributing questionnaires to the apparatus of financial managers who work in financial management agencies. The operational definition and measurement for each variables are as follow :

1. Understanding regional financial management $(X 1)$. Regional financial management is an entire activities that contains rights and obligations that are assessed from money or 
goods from regional government within the framework of regional revenue and expenditure budget. This instrument follows Permendagri 13 in 2005, this variable is measured using questionnaire with 10 questions with 1-5 Likert scale for each question.

2. Regional Financial Accounting System (X2). An integrated system that combines manual procedures with electronic processes in data retrieval, bookkeeping and reporting of all financial transactions, assets, debt and equity of all Local Government entities. This variable is measured with 1-5 Likert scale for each question that is following from previous research by Parintak (2015) and Financial Accounting Standards (SAK).

3. Internal Control Effectiveness (X3). Internal control includes organizational structure, methods and measures which has coordinated before to safe organizational wealth, check the accuracy and reliability of accounting data, encourage efficiency and encourage compliance with management policies. Following the elements by COSO and Government Regulation Number 60 in 2008 about Internal Control Systems, this variable is measured by 8 questions using 1-5 Likert scale for each question.

4. Commitment. Commitment means strong confidence and support from each officials and apparatus of the regional financial management toward goals to be achieved by the organization that is improving the financial performance of the regional government. This variable is measured by 8 questions using 1-5 Likert scale for each question.

5. Financial Performance of SKPD $(Y)$. Financial Performance SKPD in Regional Financial Management based on prevailing regulations and legislation is defined as the ability of each SKPD in order to manage regional financial that is a management of Regional Budget (APBD). This variable is measured using a questionnaire with 11 questions adapted by Permendagri No. 59 in 2007 and measured by 1-5 Likert scale for each question.

\section{RESULTS AND DISCUSSIONS}

\subsection{Results}

The number of questionnaires distributed was 150 questionnaires, and the questionnaire returned was 132 questionnaires, 7 incomplete and 18 non-returned. Validity test results for the variable understanding of internal control systems, regional financial accounting systems, effectiveness of internal control, organizational commitment and financial performance are all valid because they are above the critical value table $=0.444$. Reliability test obtained by Alpha Cronbach above the recommended critical value of 0.60 (Ghozali, 2001), so that the understanding of the control system, the regional financial accounting system, the effectiveness of internal control, organizational commitment and financial performance of SKPD leaders (Y) are declared reliable.

The test results of the classic assumption of normal distributed data indicated by normal P-P plot graphs and for multicollinearity testing based on the calculation of tolerance value indicate that there are no independent variables that have a tolerance value of more than 0.10 and all VIF variables value have a VIF value $<10$, it means that all the independent variables don't have multicollinearity relationship in regression model. Testing heteroscedasticity based on graphs where the points in the graph do not make a certain clear pattern and the points are spread above and below 0 number at the Y axis (Ghozali, 2006). So, there is no temporary heteroscedasticity for the value of autocorrelation test. Scote of Durbin Watson test is $=1.498$ that there is no autocorrelation of -2 to +2 , so it can be concluded that the regression equation is free of autocorrelation problems.

\subsection{Discussions}

Regression analysis is conducted to determine the effect of understanding regional financial management, regional financial accounting systems and effectiveness of internal control as well as organizational commitment to the financial performance of SKPD in the 
North Sulawesi government, both simultaneously and partially, also to test the predetermined research hypothesis. The results of regression analysis showed that from the two independent variables that significantly influence the financial performance of the SKPD, regression coefficient $(\beta)$ regional financial accounting system variable $(\mathrm{X} 2)$ was $46.3 \%$, greater than the effectiveness of internal control variable (X3) which is only $42,5 \%$, so it seems that the regional financial accounting system (X2) variable has a significantly greater influence on the SKPD's financial performance. Table 1 shows the result based on regression coefficient (B) where the regression equation is obtained as follows:

$$
\mathrm{Y}=-1,856+0,916 \mathrm{X} 1-0,045 \mathrm{X} 2+0,118 \mathrm{X} 3+0,049 \mathrm{X} 4+\mathrm{e}
$$

Table 1. Results of multiple regression analysis

\begin{tabular}{lccc}
\hline \multicolumn{1}{c}{ Variabel } & Coeffiecient $(\mathbf{B})$ & t & Sig \\
\hline Understanding regional financial management $\left(\mathrm{X}_{1}\right)$ & 0,816 & 19.960 & $0,000^{*}$ \\
Regional financial management system $\left(\mathrm{X}_{2}\right)$ & -0.045 & -1.196 & 0,234 \\
Effectiveness of internal control $\left(\mathrm{X}_{3}\right)$ & 0,118 & 2.261 & $0,026^{*}$ \\
Komitmen Organisasi $\left(\mathrm{X}_{4}\right)$ & 0.049 & 0.788 & 0.433 \\
\hline Constant & & & -1.856 \\
R & & & 0,819 \\
R square & & & 0,845 \\
Adjusted R Square & & & 0,840 \\
F & & & 163.351 \\
Significant F & & & 0,000 \\
\hline
\end{tabular}

Effect of Understanding Regional Financial Management Variable (X3) on Financial Performance of SKPD (Y). The result shows that the variable understanding of regional financial management $(\mathrm{X} 1)$ has a significant effect to the financial performance of SKPD (Y), Understanding is a process, action and a way to understand. Understanding according to the large dictionary of Indonesian (1991) means a process of thinking and learning, because for heading towards understanding needs to be followed with learning and thinking. the results of this study indicate that the local government awareness is increase about the importance of added up human resource capacity (capacity building) through education, training, courses or technical guidance on financial management which has an impact on improving the financial performance of financial managers. Education and training are needed to anticipate the rule changes that apply in financial management. For example the change of rules with the issuance of Permendagri 64 of 2013 requires that each local government use accrual-based accounting and technical socialization / guidance is needed to avoid mistakes from the rule changes, the new rules must be properly understood so that financial managers are able to make overall improvements due to the rule changes. The result of this research has the same result with the research of Hidayat (2009) who conducted research in Padang Pariaman Regency that shows the financial management of Padang Pariaman had a significant positive effect on the performance of regional government, and Almanda (2013) who conducted research in Bandung City, found that management Regional finance has a significant influence on the performance of local governments.

Effect of Regional Financial Accounting System Variables (X2) on SKPD Financial Performance (Y). The results of this study found that the regional financial accounting system has no significant effect on the financial performance of SKPD. Regional financial accounting systems will be running well if supported by the ability of reliable apparatus / human resources of using the computers. The technology-based regional financial accounting system is the regional management information system (SIMDA) which launched by BPKP. This application allows financial managers to produce reports faster and more 
accurate, but there may be errors due to negligence or inaccurate operators or financial manager mistakes for inputting data so that there are error in the recording account, it will make a misstatement in the finance report. In addition, there are so many local government policies regarding Regional Budget that aren't in accordance with the application SIMDA. In the application has been limited by the rules and policies issued by the central government, therefore Regional Government needs to fix regional financial policies in accordance with the system. Implementation of the application SIMDA Version 2.7 Accrual based that recently launched by BPKP is a challenge for the financial management apparatus in the district and city in North Sulawesi Province because it requires time to adjust the system. The results of this research is different with the research conducted by Parintak (2015) and Hidayat (2015) and Azhar (2007) and Warisno (2009) which devices support such as accounting information systems can affect the performance of SKPD, this research proves that regional financial accounting information systems aren't significant and positive for the performance of SKPD in the districts and cities of North Sulawesi province.

Effect of Internal Control Effectiveness Variable (X3) on SKPD's Financial Performance (Y). The internal control effectiveness variable have a significant effect and have a positive relationship to the SKPD's financial performance, the better the implementation of internal control, the better the performance of SKPD will be. Internal control financial is carried out by the inspectorate and at the same time provides necessary improvements and guidance if there are mistakes made by government officials, so that employees are willing to work diligently in carrying out their duties in accordance with the program and follow the rules. This is the same with what was disclosed by Arens (2003), the monitoring that runs well will produce a good quality of financial reports. Regional financial supervision is one of the components government internal control, namely supervision activities dealing with periodic or ongoing assessments of the quality of performance / performance of government internal control to determine that internal control operates as what expected and modified according to the conditions of changed. The system will run well if there is supervision that ensures the system runs according to plan.

Effect of Commitment Variable to the Ability of Preparing Local Government Financial Statements. In this research, the organizational commitment variable did not significantly influence the financial performance of regional government. This is because the implementing staffs have a different view or perspective from policy makers, so the process implementation of the policy also becomes ineffective which is influenced by the situation and motivation. In addition, the organizational commitment felt by the employee of financial management shows lack of strong emotional attachment to one another employees and lack of involvement employees in the workplace, lack of attention to colleagues and a workplace conditions are one indication of the weak organizational commitment of employees. Financial management officers such as PPK-SKPD and treasurer of expenditure often don't have a good working relationship. So there is an attitude of reluctance to make everything good, if the commitment of this organization wants to applied by the employees, the employees will have an impact on their performance as crushed by the top management who has committed and desire to be more advanced in financial management. There are also employees, for political reasons, make further exacerbating to the work relations that decrease the commitment of financial management officials so that financial performance was reduced. Commitment is an emotional / heart problem, not a word or just a thought. According to Kaswan $(2014 ; 117)$ If you want to be an effective leader, people must have a commitment. Without commitment, big jobs will be difficult. This research is the same with Aidil's research (2010) which says that commitment does not affect the ability of financial statement preparation because the employees who are related, have not been able to issue additional physics, mental and spiritual resources in carrying out their own assignments. 


\section{CONCLUSION}

Conclusions that can be taken based on the results of this research and analysis has been described previously can be concluded that : (a) understanding of Financial Management for financial management apparatus is needed for the accountability of regional financial management, this ability is obtained from education and training so that it will affect the financial performance of SKPD in District and city governments; (b) although the regional financial accounting system in this research has no significant effect, but it is still needed to make it easy and make it faster of the financial management, but because there are still many financial officers who have not been trained to use computers and changes in applications, this is an obstacle in financial management of regencies and cities in North Sulawesi so that it has an impact on financial performance; (c) effectiveness Internal control that carried out by the internal control apparatus is very important in overseeing the course of financial management to be careful and obedient with the administration for financial managers so it will give impact on the financial performance of the SKPD; (d) organizational commitment is still weak with various problems on regional policy and not in accordance with the rules regarding financial management so that in this research, organizational commitment has no significant influence on financial management in districts and cities in North Sulawesi; and (e) the result of this research indicate the needs of improvement human resources for SKPD financial managers in the local government and a strong determination and commitment from the leadership to realize this problem to get the best improvement of the financial performance of the SKPD.

Suggestions that can be given based on the results of the research are : (a) the researcher suggests for further research to consider other variables or explore with qualitative research methods to find out whether there are new variables that can affect financial performance; (b) regional financial managers in the regency and the city should be able to manage finance in accordance with applicable regulations to produce accountable financial performance; and (c) the regional head offices who are the holders of regional financial management, Regional Secretary as regional financial management coordinator, and Head of Regional Financial Management Work Unit (SKPKD) as Regional Financial Management Officer (PPKD) should carry out regional financial management guidance to head of SKPD and provide technical guidance in managing the APBD in each SKPD.

The authors realize that this research still has limitations and requires further improvements such as questionnaire that given to respondents assessing their own selves to their quality and possible improper value-giving, so that the measurement of all variables relies on subjective measurements or based on respondent's perception only. Subjective measurement is susceptible to the appearance of bias or measurement errors. And there are still other variables that influence financial performance outside of the variables that have studied.

\section{REFERENCES}

Abdul Halim. 2007. Accounting for Public Sector Regional Financial Accounting. Jakarta: Salemba Empat

Anthony, N. Robert, and David W. Younget. 2003. Management Control in Non-profit Organizations. 7th Edition. New York: McGraw-Hill Companies.

Arens, A., Randal J. Elder, Mark S. Beasley 2003. Auditing and Assurance Service and Integrated Approach. 9th Edition. New Jersey. Prentice Hall International Inc. 
Tuasikal Askam (2008). Influence of Supervision, Understanding of Financial Accounting and Financial Management Systems on the Performance of Local Government Work Unit Units. (Study in Maluku Province Districts and Cities) ISSN: 1410-8623.

Almanda Primadona (2013), Effect of Internal Supervision and Regional Financial Management on Local Government Performance in Bandung City Government, ejournal of University of Indonesia

Collier, M. Paull. 1997. The Power of Accounting; A Field Study of Local Financial Management in a Police Force. Aston Business School Research Institute.

Cox, T. Clifford, and I Lenry Wichmann, Jr. 1993. The State and Local Government, Auditing: A Journal of Practice \& Theory: Vol. 12 No.2. Fall.

Deddi Nordiawan. 2006. Public Sector Accounting. Jakarta: Salemba Empat

Darise, Nurlan, 2009, Regional Financial Management, Issue 2, Index, Jakarta.

Erna Sari, Saiful and Nila Aprila (2013), The Effect of Understanding Government Accounting Systems and Regional Financial Administration on Regional Financial Management Performance. Fairness Journal Volume 3, Number 3, 2013

Freeman, J. Robert and Craig D. Shoulders. 2004. Governmental And Nonprofit Accounting. New Jersey. Pearson Education. Inc.

Ghozali, Imam. (2006). Application of Multivariate Analysis with SPSS Program. Mold IV. Diponegoro University Publishing Agency, Semarang.

Jensen, M. and Meckling, W., 1976. "Theory of the Firm: Managerial Behavior, Agency Cost and Ownership Structure." Journal of Financial Economics 3 (305-360).

Kearns, S. Paula. 1993. Determinants of State Budget Periodicity: An Empirical Analysis. Public Budgeting \& Finance. Vol. 13 No. 1.

Mardiasmo. 2009. Public Sector Accounting. Yogyakarta: ANDI.

Mardiasmo.2002. Regional Autonomy and Financial Management. Yogyakarta: ANDI

Mahmudi. 2011. Public Sector Accounting. Yogyakarta: UII Press

Mahmudi, 2010, Public Sector Performance Management, Issue 2, UPP STIM YKPN, Yogyakarta

Podrug, N, 2011, "The Strategic Role of Managerial Stewardship Behavior for Achieving Corporate Engagement", Ekonomski Pregled, Vol. 62 (7-8)

Government Regulation 24 of 2005 concerning government accounting standards

Government Regulation No.58 of 2005 concerning regional financial management and accountability

Permendagri No. 59 of 2007 concerning Guidelines for Regional Financial Management

Government Regulation No.60 of 2008 concerning the Government's Internal Control System

Raharjo, Eko (2007), Agency Theory and Stewarship Theory in the Accounting Perspective, Journal of Economic Focus Vol. 2 No. June 1, 2007: 3746

Sugiyono, 2011, Quantitative, Qualitative and R \& D Research Methods, Alfabeta, Bandung.

Safrida, Nadirsyah, Usman. 2010. Effect of Accounting Understanding, Utilization of Regional Financial Accounting Information Systems and Internal Audit Roles on the Quality of Local Government Financial Reports. Journal of Accounting Research and Research. VOL. 3. NO. 2. JULY 2010. THINGS. 206-220.

Tanjung, Abdul Hafiz, 2008, Administration and Regional Financial Accounting, Alfabeta Bandung

Law No. 17, 25,33 of 2004. Regarding state finances regulating regional financial management and budgeting planning in the regions.

Wawan Sukmana, Lia Anggarsari. 2009. Effect of Internal Supervision and Implementation of Regional Financial Accounting Systems on Local Government Performance. Accounting Journal of FE Unsil, Vol. 4, no. 1, 2009. 